\title{
Kebijakan Penyelenggaraan Perumahan Masyarakat Berpenghasilan Rendah di Kabupaten Lahat Provinsi Sumatera Selatan
}

\author{
Mendra Wijaya $^{1}$, Handrisal Handrisal ${ }^{2}$ \\ 1,2Program Studi Ilmu Pemerintahan, Fakultas Ilmu Sosial dan Ilmu Politik, \\ Universitas Riau, Kota Pekanbaru, Provinsi Riau \\ ${ }_{1}^{1}$ Program Studi Ilmu Pemerintahan, Fakultas Ilmu Sosial dan Ilmu Politik, \\ Universitas Maritim Raja Ali Haji, Kota Tanjungpinang, Provinsi Kepulauan Riau \\ Corresponding Author: handrisal.88@umrah.ac.id
}

Keyword:

Policy;

Housing;

Low-Income;

Communities;

\begin{abstract}
Essentially, the implementing of regulations for the construction of housing and settlement areas are clear as the responsibility of the government, as has been described above the government's role is to determine development in the field of housing and settlement areas. The central government program with 1 (one) million subsidized houses would also pay more attention to its performance implementation, hence the existing implementing regulations will not only become passive laws. Today, in Indonesia there are still many regulations which in the end become a indication of problems in their own countries. In the context of accelerating housing development for low-income people (MBR), the government makes simple efforts in order to simplify licensing for low-income housing development. By issuing Government Regulation Number 64 of 2016 concerning Low-Income Community Housing Development, then to accelerate its implementation in the regions, it is regulated in Minister of Home Affairs Regulation Number 55 of 2017 concerning the Implementation of Licensing and Non-Licensing of Housing Development for Low-Income Communities (MBR) in the Region. This study aim to find out government policies related to the implementation of MBR housing development and to determine the implementation of Housing Development Permits for Low-Income Communities (MBR) in the Regions, especially in Lahat

Regency, South Sumatra Province.
\end{abstract}

\section{PENDAHULUAN}

Salah satu kebutuhan primer dalam kehidupan masyarkat adalah perumahan. Oleh karena itu pemerintah sebagai lembaga yang memiliki otoritas perlu menyiapkan alternatif kebijakan dalam rangka pemenuhan kebutuhan akan perumahan. Menurut (Glaeser \& Gyourko, 2018), dalam konteks pemenuhan kebutuhan akan perumahan, maka tidak akan terlepas dari diskursus kemiskinan dan masyarakat berpenghasilan rendah. Karena secara empiris masyarakat miskin dan berpenghasilan rendah tersebutlah yang menjadil kelompok masyarakat dengan hambatan terbesar dalam akses kebutuhan perumahan layak huni. Hal tersebut sejalan dengan pendapat (Mangeswuri, 2016) yang menyatakan bahwa tidak semua masyarakat mampu memenuhi kebutuhan perumahan, oleh karena itu pemerintah perlu memberikan perhatian terhadap masalah pemenuhan kebutuhan akan perumahan terutama bagi masyarakat berpendapatan rendah melalui skema fasilitas pembiayaan. Pemenuhan kebutuhan akan perumahan merupakan hak dasar setiap masyarakat dan itu merupakan tanggungjawab mutlak pemerintah yang harus mampu diperlihatkan dalam aspek ketersediaan, keterjangkauan, dan keberlanjutan (Waha \& Sondakh, 2014). 
Kebutuhan rumah terus menerus meningkat tiap tahunnya, hal ini disebabkan oleh peningkataan jumlah penduduk di perkotaan terutama diakibatkan oleh urbanisasi. Menurut Sabaruddin tingginya kebutuhan perumahan yang belum dapat terfasilitasi saat ini, menunjukan bahwa penyediaan perumahan memegang peran strategis dalam pembentukan karakter bangsa. Sehingga penyediaan perumahan secara vertikal sudah menjadi solusi yang dipilih di beberapa kota besar di dunia termasuk Indonesia saat ini (Sabaruddin, 2012). Perkotaan dengan kompleksitas permasalahan yang ada di tambah laju urbanisasi yang mencapai $4,4 \%$ pertahun membuat kebutuhan perumahann di perkotaan semakin meningkat, sementara itu ketersediaan lahan menjadi semakin langka. Kelangkaan ini menyebabkan semakin mahalnya harga lahan di pusat kota, sehingga mendorong masyarakat berpenghasilan menengah bawah tinggal di kawasan pinggiran kota yang jauh dari tempat kerja. Kondisi ini menyebabkan peningkatan biaya transportasi, waktu tempuh, dan pada akhirnya akan menurunkan mobilitas dan produktivitas masyarakat. Sedangkan sebagian masyarakat dengan sadar memaksanakan bermukim di kawasan yang tidak jauh dari pusat aktivitas ekononomi, sehingga menyebabkan ketidakteraturan tata ruang kota dan berpotensi menumbuhkan kawasan kumuh baru.

Secara umum, permasalahan penyelenggaraan perumahan adalah keterjangkauan masyarakat terhadap hunian yang layak huni, baik dalam hal pembelian rumah baru yang layak huni, maupun pembangunan rumah secara swadaya, serta masih banyaknya masyarakat yang menempati rumah tidak layak huni. Permasalahan keterjangkauan disebabkan oleh adanya ketimpangan antara pasokan (supply) dan kebutuhan (demand). Adapun ketimpangan ini terjadi karena berbagai faktor, antara lain tingginya laju pertumbuhan penduduk serta tingginya urbanisasi di perkotaan, yang tidak diimbangi dengan penyediaan hunian layak. Dari sisi demand, permasalahan utama yaitu rendahnya kemampuan masyarakat khususnya Masyarakat Berpenghasilan Rendah (MBR) dalam membeli rumah yang layak ataupun membangun secara swadaya. Rumah yang dibangun oleh pengembang untuk MBR masih terbatas jumlahnya, tidak sebanding dengan kebutuhan pada masyarakat. Untuk menjamin keterjangkauan MBR pada hunian yang layak, Pemerintah telah menyediakan bantuan pembiayan perumahan walaupun belum berjalan secara optimal.

Berdasarkan data Kementerian PUPR terdapat 11 juta rumah tangga yang belum memiliki hunian layak di Indonesia. Angka tersebut terdiri dari 7,6 juta backlog kepemilikan rumah dan 2,3 juta rumah tidak layak huni sehingga masih banyak pekerjaan yang harus dilakukan dan masalah yang harus diselesaikan oleh pemerintah ke depan. Secara umum ada 3 (tiga) masalah yang dihadapi para pengembang rumah MBR di daerah perkotaan yakni masalah keterbatasan lahan, pembiayaan, dan regulasi daerah. Penyediaan lahan terutama di kota-kota besar seperti Jakarta, Medan, Surabaya, Makasar, Palembang, dan kota lainnya sulit untuk diupayakan dalam membangun rumah MBR. Menurut Hutapea dan Suwandono, rendahnya kemampuan daya beli masyarakat berpenghasilan rendah membuat keterbatasan untuk mengakses rumah yang ditawarkan pasar serta minimnya tersedia tanah (Hutapea \& Suwandono, 2015). Di sisi yang lain, peluang yang ditawarkan pemerintah belum ada yang membantu masyarakat untuk mengakses tanah. Disinilah peran pemerintah daerah dalam mendukung kebijakan perumahan bagi MBR tersebut menjadi penting.

Selain permasalahan lahan, fokus utama sektor perumahan di Indonesia adalah yang lainnya adalah permasalahan angka backlog perumahan. Permasalahan itu tidak hanya dirasakan oleh masyarakat saja tetapi juga dirasakan oleh pengembang perumahan. Masalah yang dihadapi oleh para pelaku dalam pasar perumahan adalah sektor pembiayaan perumahan yang kurang memadai bagi peningkatan kualitas dan 
kuantitas perumahan di Indonesia. Hal ini dikarenakan karakteristik pembiayaan perumahan yaitu nilai pembiayaan yang besar dan jangka waktu yang lama.

Sementara itu dilihat dari sisi kebijakan, saat ini kebijakan yang berkenaan dengan urusan pemerintahan bidang perumahan dan kawasan permukiman mengacu pada Undang-Undang Nomor 23 Tahun 2014 tentang Pemerintahan Daerah. Berdasarkan Undang-Undang tersebut, urusan pemerintahan bidang perumahan dan Kawasan permukiman mencakup 5 (lima) sub urusan pemerintahan, yaitu; 1) Perumahan, 2) Kawasan Permukiman, 3) Perumahan dan Kawasan Permukiman Kumuh, 4) Prasarana, Sarana, dan Utilitas Umum (PSU); dan 5) Sertifikasi, Kualifikasi, Klasifikasi, dan Registrasi Bidang Perumahan dan Kawasan Permukiman.

Kebijakan perumahan dan kawasan permukiman di Indonesia tersebut mengalami perubahan yang signifikan terkait dengan pembagian urusan pemerintahan sebagaimana ditetapkan dalam undang-undang sebelumnya (Undang-Undang Nomor 32 Tahun 2004 tentang Pemerintahan Daerah). Pembagian urusan pemerintahan konkuren antara daerah provinsi dengan daerah kabupaten/kota walaupun urusan pemerintahannya sama, perbedaannya akan nampak dari skala atau ruang lingkup urusan pemerintahan tersebut. Walaupun daerah provinsi dan daerah kabupaten/kota mempunyai urusan pemerintahan masing-masing yang sifatnya tidak hierarki, namun tetap akan terdapat hubungan antara pemerintah pusat, daerah provinsi dan daerah kabupaten/kota dalam pelaksanaannya dengan mengacu pada norma, standar, prosedur, dan kriteria (NSPK) yang dibuat oleh Pemerintah Pusat. Dengan diterbitkannya Undang-Undang Nomor 23 Tahun 2014 Tentang Pemerintahan Daerah, maka daerah diberikan kewenangan sesuai Pasal 17 (1) Daerah berhak menetapkan kebijakan Daerah untuk menyelenggarakan Urusan Pemerintahan yang menjadi kewenangan Daerah, untuk merumuskan kebijakan, salah satunya adalah kebijakan mengenani urusan pemerintahan bidang perumahan dan kawasan permukiman.

Secara konseptual kebijakan publik dapat dipahami sebagai segala sesuatu yang dikerjakan atau tidak dikerjakan oleh pemerintah, urgensi dilakukannya suatu kebijakan dan apakah manfaat bagi kehidupan bersama harus menjadi pertimbangan yang holistik agar kebijakan tersebut mengandung manfaat yang besar bagi warganya dan berdampak kecil dan sebaiknya tidak menimbulkan persoalan yang merugikan, walaupun demikian pasti ada yang diuntungkan dan ada yang dirugikan, disinilah letaknya pemerintah harus bijaksana dalam menetapkan suatu kebijakan (Dye, 1992). Dalam kepustakaan Internasional, kebijakan publik di kenal dengan istilah public policy, yaitu suatu aturan yang mengatur kehidupan bersama yang harus ditaati dan berlaku mengikat seluruh warganya. Setiap pelanggaran akan diberi sanksi sesuai dengan bobot pelanggarannya yang dilakukan dan sanksi dijatuhkan didepan masyarakat oleh lembaga yang mempunyai tugas menjatuhkan sanksi (Nugroho, 2004).

Aturan atau peraturan tersebut secara sederhana kita pahami sebagai kebijakan publik, jadi kebijakan publik ini dapat kita artikan suatu hukum. Akan tetapi tidak hanya sekedar hukum namun kita harus memahaminya secara utuh dan benar. Ketika suatu isu yang menyangkut kepentingan bersama dipandang perlu untuk diatur maka formulasi isu tersebut menjadi kebijakan publik harus dilakukan dan disusun dan disepakati oleh para pejabat yang berwenang dan ketika kebijakan publik tersebut ditetapkan menjadi suatu kebijakan publik; apakah menjadi Undang-Undang, apakah menjadi Peraturan Pemerintah atau Peraturan Presiden termasuk Peraturan Daerah maka kebijakan publik tersebut berubah menjadi hukum yang harus ditaati. Pembangunan perumahan dan permukiman jika dilakukan secara sistemik akan memberikan kontribusi langsung terhadap peningkatan kesejahteraan dan pengentasan kemiskinan. Hal tersebut disebabkan karena pembangunan perumahan dapat mendorong pertumbuhan wilayah 
dan ekonomi daerah, mendukung pembangunan sosial budaya dan memberikan kontribusi nyata terhadap peningkatan lapangan kerja, pertumbuhan ekonomi, pengentasan kemiskinan dan peningkatan kesejahteran. Oleh karena itu, pembangunan perumahan dan permukiman harus dilandasi oleh suatu kebijakan, strategi dan program, kegiatan yang komprehensif dan terpadu sehingga selain mampu memenuhi hak dasar rakyat.

Kebijakan perumahan merupakan instumen yang sangat penting bagi pemerintah dalam melakukan intervensi pembangunan. Sebagaiamana temuan Festus dan Amos dalam penelitiannya bahwa kebijakan perumahan merupakan instrumen yang penting dalam upaya mendukung pembangunan nasional di Nigeria. Namun implementasi kebijakan pembangunan oleh pemerintah dengan pendekatan atas-bawah ternyata bermasalah, misalnya administrasi yang buruk, pendanaan yang tidak memadai, infrastruktur yang tidak mencukupi, dan pembiayaan perumahan yang kurang (Festus \& Amos, 2005). Masalah dalam implementasi kebijakan pembangunan dengan pendekatan atas-bawah ini umumnya juga ditemukan di negara berkembang seperti Indonesia (Kawer et al., 2018).

Terkait dengan masalah dalam implementasi kebijakan pembagunan perumahan, Van Meter dan Van Horn (dalam Winarno, 2002) mendefinisikan implementasi kebijakan sebagai tindakan-tindakan yang dilakukan oleh individu-individu (kelompok-kelompok) pemerintah maupun swasta yang diarahkan untuk mencapai tujuan yang telah ditetapakan dalam keputusan-keputusan kebijakan sebelumnya. Dalam memenuhi kebutuhan perumahan pemerintah tentu saja bermitra dengan developer, dalam praktiknya ternyata developer lebih tertarik mengembangkan rumah mewah dan menengah karena jauh lebih menguntungkan. Agar rumah yang dibangun oleh Developer harganya bisa terjangkau oleh Masyarakat Berpenghasilan Rendah (MBR) maka para Developer harus berpedoman kepada Surat Keputusan Bersama antara Menteri Dalam Negeri, Menteri Pekerjaan Umum dan Menteri Negara Perumahan Rakyat, Nomor 648381 Tahun1992, 739/KPTS/1992 dan 09/KPTS/1992 tentang Pedoman Pembangunan Perumahan dan Permukiman dengan Lingkungan Hunian yang Berimbang. Ketentuan perbandingan antara pembangunan rumah mewah, pembangunan rumah menengah dan pembangunan rumah sederhana adalah $1: 3: 6$ dan biasanya dalam membangun rumah menengah dan rumah sederhana, developer akan memilih lokasi di daerah pinggiran kota. Oleh karena itu saat ini di pinggiran Kota Palembang yang berbatasan dengan Kabupaten Ogan Ilir, Kabupaten Ogan Komering Ilir, dan Kabupaten Banyuasin pembangunan dan pertumbuhan rumah darat / rumah tapak berlangsung dengan pesat terutama untuk tipe rumah menengah dan tipe sederhana.

Skema kerjasama dengan sektor swasta dalam pembangunan perumahan, khususnya perumahan untuk MBR diupayakan melalui kebijakan pembangunan hunian berimbang. Dimulai dengan Peraturan Pemerintah Nomor 14 Tahun 2016 tentang Penyelenggaraan Perumahan dan Kawasan Permukiman sebagai aturan pelaksanaan Undang-undang Nomor 1 Tahun 2011 tentang Perumahan dan Kawasan Permukiman (Indradjati, 2020). Upaya pembangunan perumahan dan permukiman yang telah dilaksanakan selama ini, bersifat sangat sektoral dan hanya berupa proyek-proyek yang sifatnya parsial dan tidak berkelanjutan. Selain itu, upaya pembangunan perumahan yang dilakukan di daerah-daerah sangat terbatas sekali karena keterbatasan kemampuan sumber daya manusia, sumber pembiayaan maupun pengembangan pilihan-pilihan teknologi danupaya pemberdayaan masyarakat setempat yang kurang menjadi program utama(Mardiansyah \& Adisti, 2020).

Untuk mengatasi backlog dalam penyelenggaraan pemenuhan kebutuhan perumahan bagi masyarakat berpenghasilan rendah (MBR) yang menjadi prioritas 
pemerintah sudah ada kebijakan diantaranya, Undang-Undang Nomor 1 Tahun 2011 tentang Perumahan, Peraturan Pemerintah Nomor 64 tahun 2016 tentang Pembangunan Perumahan Masyarakat Berpenghasilan Rendah, Peraturan Menteri Dalam Negeri Nomor 55 tahun 2017 tentang Pelaksanaan Perizinan dan Nonperizinan Pembangunan Perumahan Bagi Masyarakat Berpenghasilan Rendah Di Daerah. Namun di dalam pelaksanaannya masih terdapat berbagai macam kendala baik teknis perizinan, insitusional serta legalistik. Peraturan Menteri Dalam Negeri Nomor 55 tahun 2017 tentang Pelaksanaan Perizinan dan Nonperizinan Pembangunan Perumahan Bagi Masyarakat Berpenghasilan Rendah Di Daerah mengamatkan dalam pasal 10 bahwa daerah membentuk Peraturan Kepala Daerah tentang kemudahan perizinan pembangunan perumahan bagi masyarakat berpenghasilan rendah sehingga kendala perizinan dapat teratasi.

Di Kabupaten Lahat jenis-jenis permukiman yang ada sangat variatif, mulai dari jenis permukiman formal dalam bentuk Perumnas, dan Ruko, hingga jenis perumahan informal dalam bentuk perumahan perkampungan, hunian liar dan rumah-rumah kumuh. Perhitungan backlog rumah mengacu pada jumlah bangunan rumah dan jumlah Kepala Keluaraga (KK), dengan asumsi perhitungan $1 \mathrm{KK}$ memiliki 1 bangunan rumah. Berdasarkan perhitungan backlog rumah, Kabupaten Lahat memiliki backlog rumah mencapai 14.775 unit rumah. Selain itu juga masih terdapat rumah yang sangat sederhana bahkan tergolong kedalam rumah yang tidak layak untuk dihuni yang tersebar di beberapa kecamatan. Jumlah keseluruhan rumah tidak layak huni yang berada di Kabupaten Lahat yaitu sejumlah 2.528 unit rumah. Kondisi ini dikarenakan rendahnya penghasilan masyarakat yang sebagian besar bermata pencaharian sebagai buruh tani, hal inilah yang menjadi alasan mendasar kenapa masyarakat tersebut tidak bisa memiliki rumah yang layak huni. Adapun data jumlah Rumah Tidak Layak Huni (RTLH) pada masing-masing kecamatan di Kabupaten Lahat sebagai berikut:

\begin{tabular}{|c|l|r|}
\hline No & \multicolumn{1}{|c|}{ Kecamatan } & Jumlah Unit RTLH \\
\hline $\mathbf{1}$ & Tanjung Sakti Pumi & 292 \\
\hline $\mathbf{2}$ & Tanjung Sakti Pumu & 132 \\
\hline $\mathbf{3}$ & Kota Agung & 175 \\
\hline $\mathbf{4}$ & Mulak Ulu & 389 \\
\hline $\mathbf{5}$ & Tanjung Tebat & 123 \\
\hline $\mathbf{6}$ & Mulak Sebingkai & 180 \\
\hline $\mathbf{7}$ & Pulau Pinang & 60 \\
\hline $\mathbf{8}$ & Pagar Gunung & 134 \\
\hline $\mathbf{9}$ & Gumay Ulu & 306 \\
\hline $\mathbf{1 0}$ & Jarai & 269 \\
\hline $\mathbf{1 1}$ & Pajar Bulan & 95 \\
\hline $\mathbf{1 2}$ & Muara Payang & 304 \\
\hline $\mathbf{1 3}$ & Sukamerindu & - \\
\hline $\mathbf{1 4}$ & Kikim Barat & 438 \\
\hline $\mathbf{1 5}$ & Kikim Timur & 366 \\
\hline $\mathbf{1 6}$ & Kikim Selatan & 555 \\
\hline $\mathbf{1 7}$ & Kikim Tengah & 325 \\
\hline $\mathbf{1 8}$ & Lahat & 377 \\
\hline $\mathbf{1 9}$ & Gumay Talang & 150 \\
\hline $\mathbf{2 0}$ & Lahat Selatan & 124 \\
\hline & & \\
\hline
\end{tabular}




\begin{tabular}{|c|l|r|}
\hline No & \multicolumn{1}{|c|}{ Kecamatan } & Jumlah Unit RTLH \\
\hline $\mathbf{2 1}$ & Peksu & 103 \\
\hline $\mathbf{2 2}$ & Merapi Barat & 117 \\
\hline $\mathbf{2 3}$ & Merapi Timur & 260 \\
\hline $\mathbf{2 4}$ & Merapi Selatan & 375 \\
\hline Kabupaten Lahat & $\mathbf{5 . 6 9 4}$ \\
\hline
\end{tabular}

Dengan memperhatikan kondisi permasalahan di atas, penelitian bertujuan untuk menganalisis bagaimana kebijakan penyelenggaraan pembangunan perumahan bagi masyarakat berpenghasilan rendah (MBR) di Kabupaten Lahat Provinsi Sumatera Selatan.

\section{METODE PENELITIAN}

Penelitian ini merupakan penelitian deskriptif yang bertujuan untuk mengetahui nilai satu variable atau lebih tanpa membuat perbandingan ataupun mengananalisis hubungan antar variabel satu dengan variabel yang lain. Pendekatan penelitian yang digunakan adalah pendekatan kualitatif dengan menganalisis data primer maupun data sekunder (Sugiyono, 2009). Dengan pendekatan kualitatif, penelitian ini diharapkan mampu menggali data secara lebih mendalam dan mendapatkan kondisi yang ada secara faktual pada dinas yang dijadikan lokus penelitian, sehingga tujuan penelitian dapat tercapai.

Penelitian kualitatif merupakan suatu proses penelitian yang dapat digunakan untuk menyelidiki suatu fenomena sosial dan masalah manusia. Pada penelitian ini peneliti membuat suatu gambaran kompleks, meneliti kata-kata, laporan terinci dari pandagan responden dan melakukan studi pada situasi yang alami (Iskandar, 2009). Dalam penelitian ini pengumpulan data dilakukan dengan cara mengumpulkan data sekunder dari Perangkat Daerah terkait berupa Laporan Penerapan dan Pencapaian Standar Pelayanan Minimal dinas, Renstra, Renja, laporan tahunan, Lakip, dan studi kepustakaan (library research) dalam rangka memperkaya penelitian berupa buku, jurnal, hasil penelitian serta informasi-informasi lainnya yang menunjang penelitian ini.

\section{HASIL DAN PEMBAHASAN \\ Kebijakan Perumahan dan Kawasan Permukiman}

Dasar perumusan kebijakan RPJMN IV tahun 2020 -2025 adalah terpenuhinya kebutuhan hunian yang dilengkapi dengan prasarana dan sarana pendukungnya bagi seluruh masyarakat yang didukung oleh sistem pembiayaan perumahan jangka panjang yang berkelanjutan, efisien dan akuntabel untuk mewujudkan kota tanpa permukiman kumuh. Sedangkan SDGs 11 goalnya adalah menjamin akses bagi semua terhadap perumahan yang layak, aman, terjangkau, dan pelayanan dasar, serta menata kawasan kumuh.

Dengan perumusan kebijakan RPJMN IV tahun 2020 -2025 diatas, untuk itulah pemerintah perlu melakukan inovasi kebijakan penyediaan perumahan dengan 3 cara yaitu : (1) Pembangunan inklusif perumahan untuk dapat menggerakan potensi besar kemampuan masyarakat MBR dalam hal penyediaan perumahan secara swadaya, (2) Program Pembangunan Perumahan Berbasis Komunitas (P2BK), (3) Menjangkau Non Fixed Income atau Non Bankable Community, (4) Melalui Perluasan : KPR Mikro, BSPS PB, dan Bantuan PSU Perumahan. 
Kebijakan Perumahan dan permukiman disetiap Kabupaten/Kota dirumuskan dengan melihat arah kebijakan pembangunan dan penataan ruang Kabupaten/Kota terkait dengan penanganan kawasan perumahan dan permukiman, kondisi eksisting kawasan perumahan dan permukiman, isu strategis kawasan perumahan dan permukiman, dan kebutuhan penanganan kawasan perumahan dan permukiman. Kemudian kebijakan penanganan kawasan Perumahan dan permukiman yang telah dirumuskan, akan dijabarkan ke dalam strategi penanganan kawasan perumahan dan permukiman, yang kemudian akan dirumuskan dalam bentuk program penanganan kawasan perumahan dan permukiman. Kebijakan Perumahan dan Kawasan Permukiman Berdasarkan RPJMD dituangkan dalam salah satu misi RPJMD Kabupaten Lahat Tahun 2019-2023 yaitu Meningkatkan pembangunan infrastruktur publik berbasis pada pemerataan wilayah yang memadai dan efektif. Adapun tujuan dan sasaran dari misi tersebut meliputi: (1) Meningkatnya kapasitas infrastruktur wilayah; (2) Terbangunnya jaringan infrastruktur perhubungan yang terpadu dan merata ke seluruh wilayah; (3) Meningkatnya Kualitas dan Kuantitas jaringan Irigasi, Rawa serta Jaringan Irigasi Lainnya. (4) Tersedianya sarana dan prasarana dasar permukiman. (5) Terwujudnya kesesuaian pemanfaatan ruang; (7) Meningkatnya kualitas lingkungan hidup.

Kawasan perumahan dan permukiman perlu ditangani dengan cara yang menyeluruh, sehingga diperlukan arah yang jelas dalam pendekatan yang digunakan dalam penanganan kawasan perumahan dan permukiman. Penangan kawasan Perumahan dan Permukiman di Kabupaten/Kota dilaksanakan dengan tujuan untuk mewujudkan Kabupaten/Kota bebas kumuh guna mendukung untuk menjadi kabupaten/kota metropolitan yang berdaya saing, nyaman, peduli dan sejahtera. Dari pada itu, konsep yang dilakukan oleh pemerintah dalam kebijakan nasional pembangunan bidang perumahan tahun 2020 -2024 yaitu dengan membuat : (1) Program Sejuta Rumah, (2) tantangan Infrastruktur perumahan, (3) Kendala yang diupayakan dalam pembangunan sejuta rumah, dan (4) Membuat konsep kebijakan pemerintah tahun 2020 -2024 di bidang Perumahan. Pola permukiman di Kabupaten Lahat dapat dikelompokkan sebagai berikut:

a. Permukiman Swadaya. Pola permukiman ini mempunyai karakteristik, sebagai berikut:

a. Tumbuh secara alami, spontan dan letaknya mendekati tempat kerjanya

b. Tidak memperhatikan komposisi ruang terbangun dan resapan

c. Diusahakan secara swadaya oleh masyarakat

d. Pola cenderung tidak teratur (biasanya mengikuti pola kontur)

e. Tampilan antar bangunan cenderung berbeda satu sama lain.

b. Permukiman Perkotaan. Adalah permukiman swadaya yang terletak di kawasan pusat Kabupaten Lahat. Permukiman jenis ini mempunyai kawasan yang teratur dan terencana maupun kawasan yang tumbuh secara spontan, swadaya dan tidak teratur.

c. Permukiman Perdesaan. Adalah permukiman swadaya yang terletak di kawasan pinggiran Kabupaten Lahat. Permukiman jenis ini mempunyai pola kawasan yang tumbuh secara spontan, swadaya dan tidak teratur. Saat ini cendernung memiliki bentuk rumah tradisonal serta berada di sepanjang jalan utama;

d. Permukiman Developer/ Perumahan Pola permukiman ini mempunyai karakteristik, sebagai berikut:

1. Tumbuh secara terencana

2. Memperhatikan komposisi ruang terbangun dan resapan

3. Diusahakan secara terencana oleh developer, instansi, industri, dll

4. Pola cenderung teratur

5. Tampilan antar bangunan cenderung sama. 
Tantangan yang dihadapi pemerintah dalam membangun Infrastruktur Perumahan bagi masyarakat adalah: (1) Kebutuhan Perumahan Generasi Millenials (jumlah penduduk tahun 2019; + 81 juta jiwa, (2) Jumlah Backlog yang masih besar 7,6 juta rumah dan 2,3 juta RTLH, dan (3) Peningkatan kualitas Perumahan dan Permukiman. Selanjutnya tantangan yang dihadapi oleh pemerintah dalam membuat kebijakan perumahan adalah nilai backlog rumah dan rumah tidak layak huni yang masih sangat besar dengan rincian sebagai berikut, Data BPS tahun 2015 adalah 11,4 juta backlog dan 3,4 juta backlog RTLH. Sedangkan Program Sejuta Rumah (PSR) tahun 2015-2019 adalah Pembangunan Rumah Baru (PRB) sebanyak 3.772.160 unit dan Peningkatan Kualitas Rumah Tidak Layak Huni (PKRTLH) sebanyak 1.020.158 unit. Sehingga diperkirakan pemerintah akan menghadapi defisit perumahan di tahun 2020 sebesar 7,63 juta backlog rumah dan 2,38 juta backlog Rumah Tidak Layak Huni (RTLH), kemudian dapat dirinci defisit perumahan tahun 2020 adalah sebagai berikut : (a) + 6,63 juta backlog Rumah MBR Non Fixed Income, (b) + 1,1 juta Backlog Rumah MBR Fixed Income, dan (3) + 2,38 juta backlog RTLH MBR Non Fixed Income.

\section{Kebijakan Pembangunan Perumahan Bagi Masyarakat Berpenghasilan Rendah di Kabupaten Lahat}

Peraturan Menteri Dalam Negeri Nomor 55 Tahun 2017 Tentang Pelaksanaan Perizinan dan Nonperizinan Pembangunan Perumahan Bagi Masyarakat Berpenghasilan Rendah (MBR) bertujuan untuk memberikan kepastian hukum agar (a) Pembangunan Perumahan bagi MBR di daerah dilaksanakan secara tertib dan berkeadilan; dan (b) Pemerintah Daerah dan Badan Hukum melaksanakan tugas dan wewenang serta hak dan kewajiban dalam pembangunan Perumahan bagi MBR di daerah dengan cepat, efisien, dan efektif. Pada Pasal 3 dijelaskan bahwa Pemerintah Daerah memberikan kemudahan kepada Badan Hukum yang akan melaksanakan pembangunan Perumahan bagi MBR di daerah untuk memenuhi kebutuhan Rumah bagi MBR. Kemudahan yang dimaksud berupa Perizinan dan Nonperizinan pada tahapan pembangunan Perumahan bagi MBR, yaitu: a) persiapan; b) prakonstruksi; c) konstruksi; dan d) pascakonstruksi.

Badan hukum melaksanakan pembangunan Perumahan bagi MBR dengan dilengkapi pembangunan Prasarana, Sarana, dan Utilitas Umum. Prasarana, Sarana, dan Utilitas Umum yang telah selesai dibangun oleh Badan Hukum diserahterimakan kepada Pemerintah Daerah secara bertahap sesuai dengan ketentuan peraturan perundangundangan. Badan Hukum yang melaksanakan pembangunan Perumahan bagi MBR di daerah dilakukan untuk luas lahan tidak lebih dari 5 (lima) hektar dan paling sedikit 0,5 (nol koma lima) hektar, serta berada dalam 1 (satu) lokasi yang diperuntukkan bagi pembangunan Rumah tapak. Pelaksanaan pembangunan ini tidak dikenakan biaya. Lahan harus berada pada lokasi yang telah sesuai dengan peruntukannya dengan Rencana Tata Ruang Wilayah. Dalam hal Rencana Tata Ruang Wilayah belum tersedia, Pemerintah Daerah menyiapkan Pertimbangan Teknis Penatagunaan Tanah/Advise Planning untuk kawasan Perumahan MBR yang dimohonkan.

Pemerintah Daerah melalui Dinas Penanaman Modal dan PTSP memberikan kemudahan pelaksanaan Perizinan dan Nonperizinan pembangunan Perumahan bagi MBR. Kemudahan pelaksanaan Perizinan dan Nonperizinan dilakukan melalui Penyederhanaan Pelayanan yaitu: a) penghapusan Perizinan; b) penggabungan Perizinan; dan c) percepatan waktu penyelesaian. Penghapusan perizinan yaitu berupa izin lokasi, rekomendasi peil banjir, izin cut and fill dan analisa dampak lingkungan lalu lintas sedangkan penggabungan Perizinan dilakukan terhadap :

a. proposal pembangunan Perumahan bagi MBR yang diajukan badan hukum digabung dengan surat pernyataan tidak sengketa jika tanah belum bersertifikat; 
b. izin pemanfaatan tanah/izin pemanfaatan ruang digabung dengan tahap pengecekan kesesuaian rencana umum tata ruang/rencana detail tata ruang wilayah dan pertimbangan teknis penatagunaan tanah/advise planning; dan

c. pengesahan site plan diproses bersamaan dengan surat pernyataan pengelolaan lingkungan, rekomendasi pemadam kebakaran, dan penyediaan lahan pemakaman.

Sementara itu Percepatan waktu penyelesaian dilakukan terhadap :

a. surat pelepasan hak atas tanah dari pemilik tanah kepada Badan Hukum dengan waktu penyelesaian paling lama 3 (tiga) hari;

b. surat permohonan, persetujuan dan pengesahan gambar site plan dengan waktu penyelesaian paling lama 7 (tujuh) hari;

c. pengukuran dan pembuatan peta bidang tanah dengan waktu penyelesaian paling lama 14 (empat belas) hari;

d. penerbitan Izin Mendirikan Bangunan Induk dan pemecahan Izin Mendirikan Bangunan dengan waktu penyelesaian paling lama 3 (tiga) hari; dan

e. evaluasi dan penerbitan Surat Keputusan tentang Penetapan Hak atas Tanah dengan waktu penyelesaian paling lama 3 (tiga) hari.

Dalam hal Dinas Penanaman Modal dan PTSP belum terbentuk, pelaksanaan Perizinan dan Nonperizinan dilakukan melalui perangkat daerah yang secara teknis menangani urusan terkait. Pelaksanaan Perizinan dan Nonperizinan dipublikasikan kepada masyarakat sesuai dengan ketentuan peraturan perundang-undangan. Untuk percepatan pelaksanaan Perizinan dan Nonperizinan pembangunan Perumahan bagi MBR di daerah, Pemerintah Daerah provinsi dan kabupaten/kota mendelegasikan wewenang pemberian Perizinan dan Nonperizinan terkait dengan pembangunan Perumahan bagi MBR kepada Kepala Dinas Penanaman Modal dan PTSP.

Kebijakan percepatan dan kemudahan perizinan pembangunan perumahan bagi MBR belum sepenuhnya dilaksanakan di daerah secara konsisten. Hal ini terlihat dari jumlah Pemerintah Daerah yang menyusun peraturan terkait kemudahan perizinan sebagai tindak lanjut dari Peraturan Pemerintah Nomor 64 Tahun 2016 tentang Pembangunan Perumahan MBR serta amanat Pasal 10 Peraturan Menteri Dalam Negeri Nomor 55 tahun 2017 tentang Pelaksanaan Perizinan dan Nonperizinan Pembangunan Perumahan Bagi Masyarakat Berpenghasilan Rendah di Daerah bahwa daerah membentuk Peraturan Kepala Daerah dalam rangka kemudahan pelaksanaan Perizinandan Nonperizinan pembangunan Perumahan bagi MBR. Sampai dengan tahun 2019, Pemerintah Daerah yang teridentifikasi telah menerbitkan Perkada tentang kemudahan perizinan pembangunan perumahan MBR, yaitu sebanyak 4 (empat) Kabupaten/Kota yaitu Kota Prabumulih, Kabupaten Muara Enim, Kabupaten Sleman, dan Kota Pontianak. Kemudian sebanyak 3 (tiga) Provinsi telah menerbitkan SE Gubernur perihal Percepatan Pembangunan Perumahan MBR yaitu Provinsi Sulawesi Selatan, Provinsi Sumatera Utara dan Provinsi Sumatera Selatan.

Sementara Kabupaten/Kota yang sedang dalam proses pengesahan Perkada terdapat 3 (tiga) Kabupaten/ Kota, yaitu Kota Tomohon, Kota Manado, Kota Lubuk Linggau. Selanjutnya, terdapat 5 (lima) Kabupaten/Kota yang telah menyediakan SOP Penyederhanaan Perizinan Perumahan yaitu Kota Surabaya, Kota Balikpapan, Kota Tangerang Selatan, Kabupaten Muara Enim Kabupaten Sumedang dan Kabupaten Tangerang. Belum banyaknya daerah yang menerapkan kebijakan tersebut akan menghambat pengembang, tidak terkecuali pengembang yang membangun rumah untuk MBR, dalam membangun perumahan. Permasalahan lain terkait pelaksanaan kebijakan ini, adalah belum cukup kuatnya sinergi kebijakan dan stakeholder bidang perumahan dan kawasan permukiman meskipun telah dibentuk Kelompok Kerja Perumahan dan 
Kawasan Permukiman (Pokja PKP) untuk dapat memfasilitasi penyelesaian permasalahan hambatan perizinan bidang perumahan.

Pemerintah Provinsi Sumatera Selatan menindaklanjuti Paket Kebijakan Ekonomi XIII Pemerintahan Jokowi dan amanat Permendagri Nomor 55 Tahun 2017 tentang Pelaksanaan Perizinan dan Non Perizinan Pembangunan Perumahan bagi Masyarakat Berpenghasilan Rendah di Daerah, mengeluarkan Surat Edaran No 056/Se/Perkim/2019 tentang Kemudahan Perizinan Pembangunan Rumah Bersubsidi bagi Masyarakat di Sumatera Selatan. Surat edaran dimaksudkan untuk memberikan arahan dan pembinaan kepada Bupati/Walikota se-Sumatera Selatan, kepala perangkat daerah di lingkungan Pemerintahan Provinsi Sumatera Selatan, Pimpinan Perbankan, GM PT.PLN Wilayah, Direktur Perum Perumnas, Ketua DPD REI Sumsel dan ketua DPD Apersi Sumsel tentang pemberian kemudahan perizinan dan non perizinan dalam pembangunan perumahan masyarakat berpenghasilan rendah (MBR). Adapun arahan gubernur dalam surat edaran tersebut adalah:

a. Melakukan penyederhanaan dan penurunan biaya perizinan pembangunan perumahan MBR sesuai Permendagri Nomor 55 Tahun 2017 dalam rangka mencapai target pembangunan satu juta rumah dan meningkatkan akses masyarakat mendapat rumah, percepatan perizinanan pembangunan rumah tapak bagi MBR dengan luasan kurang dari lima hektar, dan mendorong iklim berusaha bagi badan hukum dalam rangka pemenuhan kebutuhan perumahan bagi MBR.

b. Melaksanakan penyederhanaan perizinan dari 33 izin dan tahapan menjadi 11 izin dan rekomendasi.

c. Pengurangan waktu perizinan, penggabungan proses perizinan dan percepatan penyelesaian perizinan.

d. Memberikan pengurangan BPHTB dan Retribusi Izin Mendirikan Bangunan bagi MBR

e. Tahapan pelaksanaan pembangunan MBR, yaitu: persiapan; prakonstruksi; konstruksi; dan pascakonstruksi.

f. Melaksanakan pembinaan dan pengawasan pembangunan perumahan MBR sesuai amanat UU.

g. Melaksanakan pembagian urusan kewenangan dan mengalokasikan anggaran dari APBD pada perangkat daerah Bidang PKP terutama penyelenggaraan PSU.

h. Menerbitkan Peraturan Bupati/Walikota tengan IMB khusus rumah bersubsidi bagi MBR.

i. Menyampaian laporan berkala setiap enam bulan.

j. Penyediaan basis data PKP dan pembentukan Pokja PKP.

k. Membentuk Tim Koordinasi Percepatan Pembangunan Rumah Bersubsidi bagi MBR yang diketuai Sekda.

Dalam pelaksanaannya Kabupaten Lahat belum dapat menjalankan Amanah Pasal 10 Peraturan Menteri Dalam Negeri Nomor 55 tahun 2017 tentang Pelaksanaan Perizinan dan Nonperizinan Pembangunan Perumahan Bagi Masyarakat Berpenghasilan Rendah di Daerah yaitu untuk simplikasi perizinan pembangunan perumahan masyarakat berpenghasilan rendah maka dibentuk dengan Peraturan Kepala Daerah. Hal ini disebabkan adalah belum adanya Peraturan Daerah tentang perumahan dan Kawasan permukian, peraturan daerah tentang penyelenggaraan penyerahan prasarana, sarana dan utilitas perumahan di daerah serta peraturan daerah tentang Rencana Pembangunan dan Pengembangan Perumahandan Kawasan Permukiman (RP3KP) yang menjadi pedoman umum dalam pengaturan dan penyelengaraan urusan pemerintahan bidang perumahan dan Kawasan permukiman. Meskipun demikian secara teknis pemerintah daerah Kabupaten Lahat sudah memiliki Peraturan Bupati Lahat Nomor 9 Tahun 2018 tentang Pendelegasian Seluruh Kewenangan Penerbitan Perizinan dan Nonperizinan 
Kepada Kepala Dinas Penanaman Modal dan Pelayanan Terpadu Satu Pintu yang secara teknis sudah mengakomodasi kebutuhan simplifikasi perizinan sesuai dengan substansi Peraturan Menteri Dalam Negeri Nomor 55 tahun 2017 tentang Pelaksanaan Perizinan dan Nonperizinan Pembangunan Perumahan Bagi Masyarakat Berpenghasilan Rendah di Daerah.

\begin{tabular}{|c|c|c|c|c|}
\hline Jenis Layanan & $\begin{array}{c}\text { Waktu } \\
\text { Penyelesaian }\end{array}$ & Biaya Tarif & Produk Pelayanan & $\begin{array}{c}\text { PD } \\
\text { Penerbi }\end{array}$ \\
\hline Izin Lokasi & 7 Hari Kerja & $\begin{array}{l}\text { Tidak dipungut } \\
\text { biaya }\end{array}$ & $\begin{array}{l}\text { Dokumen Perizinan } \\
\text { (Izin Lokasi) }\end{array}$ & PTSP \\
\hline $\begin{array}{l}\text { Izin } \\
\text { Peruntukan } \\
\text { Penggunaan } \\
\text { Tanah (IPPT) }\end{array}$ & 7 Hari Kerja & $\begin{array}{l}\text { Tidak dipungut } \\
\text { biaya }\end{array}$ & $\begin{array}{l}\text { Dokument Perizinan } \\
\text { (Izin Peruntukan } \\
\text { Penggunaan Tanah - } \\
\text { IPPT-) }\end{array}$ & PTSP \\
\hline $\begin{array}{l}\text { IMB Rumah } \\
\text { Tinggal }\end{array}$ & 14 Hari Kerja & $\begin{array}{l}\text { Tidak dipungut } \\
\text { biaya }\end{array}$ & $\begin{array}{l}\text { Izin Mendirikan } \\
\text { Bangunan (IMB) }\end{array}$ & PTSP \\
\hline $\begin{array}{lr}\text { IMB } & \text { Non } \\
\text { Rumah Tinggal }\end{array}$ & 14 Hari Kerja & $\begin{array}{l}\text { Tidak dipungut } \\
\text { biaya }\end{array}$ & $\begin{array}{l}\text { Izin Mendirikan } \\
\text { Bangunan (IMB) }\end{array}$ & \\
\hline $\begin{array}{l}\text { Sertifikat Laik } \\
\text { Fungsi }\end{array}$ & 7 Hari Kerja & $\begin{array}{l}\text { Tidak dipungut } \\
\text { biaya }\end{array}$ & $\begin{array}{l}\text { Dokumen Perizinan } \\
\text { Sertifikat Laik Fungsi }\end{array}$ & PTSP \\
\hline $\begin{array}{l}\text { Surat Izin Peil } \\
\text { Banjir }\end{array}$ & 7 Hari Kerja & $\begin{array}{l}\text { Tidak dipungut } \\
\text { biaya }\end{array}$ & Surat Izin Peil banjir & PTSP \\
\hline $\begin{array}{l}\text { Analisis } \\
\text { Dampak Lalu } \\
\text { Lintas }\end{array}$ & 7 Hari Kerja & $\begin{array}{l}\text { Tidak dipungut } \\
\text { biaya }\end{array}$ & \begin{tabular}{lr}
\multicolumn{2}{l}{ Dokumen perizinan / } \\
Non & Perizinan \\
(Analisis & Dampak \\
Lalu Lintas) & \\
\end{tabular} & PTSP \\
\hline
\end{tabular}

Tabel 2: Jenis Layanan Perizinan Pembangunan Perumahan

Sumber : Peraturan Bupati Lahat Nomor 9 Tahun 2018 tentang Pendelegasian Seluruh Kewenangan Penerbitan Perizinan dan Nonperizinan Kepada Kepala Dinas Penanaman Modal dan Pelayanan Terpadu Satu Pintu

\section{Faktor Penghambat Penyelenggaraan Pembangunan Perumahan Masyarakat Berpenghasilan Rendah}

Masalah dalam pemenuhan kebutuhan perumahan bagi MBR menjadi prioritas Pemerintah dengan mengeluarkan kebijakan antara lain; Undang-Undang Nomor 1 Tahun 2011 tentang Perumahan, Peraturan Pemerintah Nomor 64 tahun 2016 tentang Pembangunan Perumahan Masyarakat Berpenghasilan Rendah, Peraturan Menteri Dalam Negeri Nomor 55 tahun 2017 tentang Pelaksanaan Perizinan dan Nonperizinan Pembangunan Perumahan Bagi Masyarakat Berpenghasilan Rendah di Daerah. Ada beberapa hal yang menjadi faktor penghambat atau kendala dalam penyelenggaraan perizinan pembangunan perumahan masyarakat berpenghasilan rendah.

a. Perbedaan Pengaturan Kewenangan Penyelenggaraan Perumahan dan Kawasan Permukiman. Terdapat perbedaan kewenangan antara Undang-Undang Nomor 23 Tahun 2014 tentang Pemerintah Daerah dan Undang-Undang Nomor 1 Tahun 2011 tentang Perumahan dan Kawasan Permukiman, terutama terkait pembagian kewenangan pemerintah pusat, provinsi, dan daerah dalam penyediaan rumah bagi Masyarakat Berpenghasilan Rendah (MBR). Pembagian kewenangan tersebut lebih jelasnya pada tabel berikut: 


\begin{tabular}{|c|c|c|c|c|}
\hline No. & $\begin{array}{l}\text { Sub- } \\
\text { Urusan }\end{array}$ & $\begin{array}{l}\text { Pemerintah } \\
\text { Pusat }\end{array}$ & $\begin{array}{l}\text { Daerah } \\
\text { Provinsi }\end{array}$ & $\begin{array}{l}\text { Daerah } \\
\text { Kabupaten/Kota }\end{array}$ \\
\hline 1. & Perumahan & 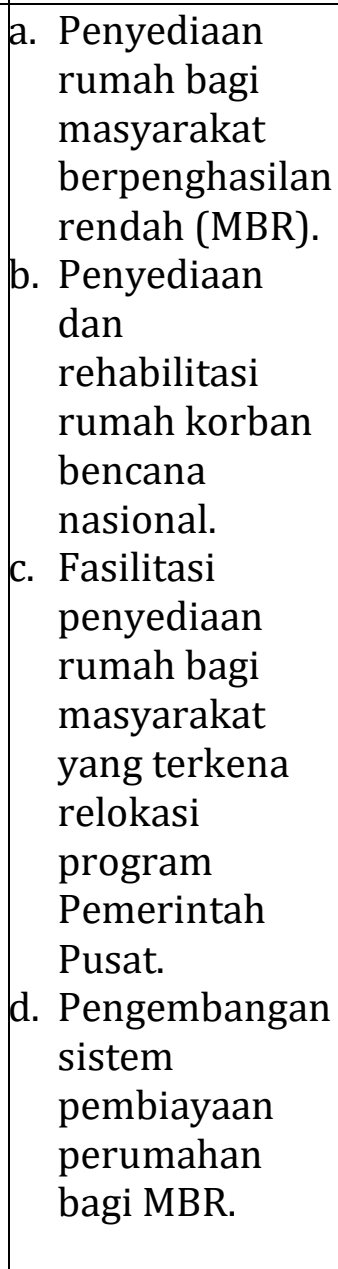 & $\begin{array}{ll}\text { a. } & \text { Penyediaan } \\
\text { dan } & \text { rehabilitasi } \\
\text { rumah } \\
\text { korban } \\
\text { bencana } \\
\text { provinsi. } \\
\text { b. } & \text { Fasilitasi } \\
\text { penyediaan } \\
\text { rumah bagi } \\
\text { masyarakat } \\
\text { yang } \\
\text { terkena } \\
\text { relokasi } \\
\text { program } \\
\text { Pemerintah } \\
\text { Daerah } \\
\text { provinsi. }\end{array}$ & $\begin{array}{l}\text { a. Penyediaan dan } \\
\text { rehabilitasi } \\
\text { rumah korban } \\
\text { bencana } \\
\text { kabupaten/ } \\
\text { kota. } \\
\text { b. Fasilitasi } \\
\text { penyediaan } \\
\text { rumah bagi } \\
\text { masyarakat } \\
\text { yang terkena } \\
\text { relokasi } \\
\text { program } \\
\text { Pemerintah } \\
\text { Daerah } \\
\text { kabupaten/kota. } \\
\text { c. Penerbitan izin } \\
\text { pembangunan } \\
\text { dan } \\
\text { pengembangan } \\
\text { perumahan. } \\
\text { d.Penerbitan } \\
\text { sertifikat } \\
\text { kepemilikan } \\
\text { bangunan } \\
\text { gedung (SKBG). }\end{array}$ \\
\hline
\end{tabular}

Undang-Undang Nomor 23 Tahun 2014 yang menyatakan bahwa urusan penyediaan rumah bagi MBR hanya merupakan kewenangan Pemerintah Pusat, sehingga membatasi Pemerintah Daerah untuk mendukung terwujudnya pembangunan untuk perumahan bagi MBR, serta berkontribusi dalam mengurangi angka backlog perumahan dan RTLH. Hal ini juga berdampak pada tidak tercapainya target akibat beban yang diberikan kepada Pemerintah Pusat untuk membangun rumah bagi MBR yang cukup besar namun tidak diimbangi dengan ketersediaan anggaran. Peran aktif seluruh stakeholder di bidang perumahan untuk menyelesaikan backlog tersebut, antara lain pemda dalam hal perizinan dan penetapan tata ruang, pengembang untuk meningkatkan pembangunan rumah dengan harga yang terjangkau serta masyarakat itu sendiri untuk membangun rumah yang layak huni secara swadaya mengalami stagnasi karena pemerintah daerah tidak memiliki kewenangan dalam pembangunan perumahan bagi masyarakat berpenghasilan rendah.

\section{Ambiguitas Pengaturan Dalam Pembangunan Perumahan MBR}

Pemerintah sudah mengeluarkan Peraturan Pemerintah Nomor 64 Tahun 2016 tentang Pembangunan dan Perumahan MBR, penerapannya di daerah Kabupaten/Kota masih belum sepenuhnya sesuai harapan. Padahal sesuai dengan Peraturan Pemerintah Nomor 64 tahun 2016 tersebut pemerintah sudah memasukan pemberian kemudahan 
perizinan berupa pengesahan site plan dan penerbitan IMB bagi pengembang yang membangun rumah MBR khususnya rumah tapak dengan luas lahan 0,5-5 hektare (ha), yang kemudian ditambah dengan berupa kemudahan persyaratan, pelayanan, serta percepatan waktu penyelesaian perizinan.

Selain itu, perizinan yang dibolehkan untuk digabung yaitu proposal MBR terkait pernyataan lahan yang tidak sengketa, izin pemanfaatan ruang dengan proses pengecekan atau kesesuaian rencana, pengesahan site plan dengan pernyataan pengelolaan lingkungan atau rekomendasi pemadam kebakaran dan lain-lain. Dengan adanya instruksi dari presiden dalam pemberian perizinan yang dipercepat, untuk itulah Terkait percepatan waktu pengurusan hak atas tanah dari pemilik diharapkan maksimal bisa tiga hari. Untuk kedepannya bahkan mungkin bisa dalam hitungan jam.

Di dalam sisi pembebasan lahan, Kementerian Dalam Negeri mengeluarkan Peraturan Menteri Dalam Negeri Nomor 55 tahun 2017 tentang Pelaksanaan Perizinan dan Non Perizinan Pembangunan Perumahan Bagi Masyarakat Berpenghasilan Rendah. Peraturan ini dikeluarkan sebagai dorongan dan pedoman Pemerintah Daerah untuk mempermudah perizinan pembangunan perumahan bagi MBR. Pemerintah Daerah dalam Peraturan Menteri Dalam Negeri Nomor 55 tahun 2017 sesuai dengan kewenangannya adalah memfasilitasi dalam hal penunjukan lahan bagi pembangunan rumah MBR (Masyarakat Berpenghasilan Rendah). Untuk itulah peran pemerintah daerah sangat krusial. Jika tidak ada pembebasan lahan dan perizinan, program satu juta rumah murah sulit dibangun pemerintah pusat. Pemerintah Daerah memfasilitasi penunjukan lahan dan mempermudah perizinan, karena untuk pembangunan rumah bagi MBR adalah kewenangan pemerintah pusat.

Selain dengan percepatan permasalahan perizinan pembangunan perumahan MBR, untuk itu pemerintah juga memikirkan permasalahan defisit perumahan (backlog perumahan), dimana definisi sederhana backlog perumahan adalah gap antara kebutuhan rumah dengan jumlah rumah yang ada. Pokok permasalahan backlog perumahan bukan hanya pada kuantitas jumlah rumah yang terbangun, namun lebih kepada jumlah kebutuhan rumah yang layak terutama bagi masyarakat berpenghasilan rendah.

Dalam Pasal 2 ayat (1) berbunyi pembangunan perumahan MBR dilakukan untuk luas lahan tidak lebih dari 5 (lima) hektare dan paling kurang 0,5 (nol koma lima) hektare serta berada dalam 1 (satu) lokasi yang diperuntukkan bagi pembangunan Rumah tapak. Kemudian dalam Kementerian Dalam Negeri mengeluarkan Peraturan Menteri Dalam Negeri Nomor 55 tahun 2017 tentang Pelaksanaan Perizinan dan Non Perizinan Pembangunan Perumahan Bagi Masyarakat Berpenghasilan Rendah di Daerah Pasal 5 (1) Badan Hukum yang melaksanakan pembangunan Perumahan bagi MBR di daerah dilakukan untuk luas lahan tidak lebih dari 5 (lima) hektar dan paling sedikit 0,5 (nol koma lima) hektar, serta berada dalam 1 (satu) lokasi yang diperuntukkan bagi pembangunan rumah tapak.

Jika kedua pasal dari peraturan perundang-undangan diatas, maka kebutuhan pemenuhan rumah MBR tidak dapat terlaksana, karena peraturan tersebut hanya membatasi untuk rumah tapak. Sedangkan kota Palembang relatif tidak memiliki lahan peruntukan untuk pembangunan perumahan MBR bagi rumah tapak, kecuali lahan untuk rumah susun. Lahan merupakan permasalahan klasik yang sering ditemui dalam penyediaan perumahan. Permasalahan lahan secara umum adalah harganya yang tinggi dan ketersediaan yang terbatas di kawasan perkotaan. Penyediaan lahan dengan luasan dan harga memadai untuk dijadikan lokasi pembangunan rumah khususnya di perkotaan menjadi hal yang sulit. Hal ini menyebabkan munculnya masalah kelangkaan lahan yang 
berakibat pada harga tanah menjadi naik serta harga rumah menjadi lebih mahal dan tidak terjangkau oleh MBR.

\section{KESIMPULAN}

Rumah Tidak Layak Huni (RTLH) di Kabupaten Lahat mencapai 5.694 unit yang tersebar di seluruh Kecamatan Kabupaten Lahat. Pemerintah Kabupaten Lahat telah mengupayakan program-program dari pusat seperti program sejuta rumah, Program Bantuan Stimulan Perumahan Swadaya (BSPS) dari Kementerian PUPR, Bantuan Rumah Swadaya dan lainnya. Mengingat tidak adanya kewenangan pemerintah daerah dalam penyelenggaraan perumahan bagi masyarakat berpenghasilan rendah sesuai dengan Undang-Undang Nomor 23 Tahun 2014 tentang Pemerintahan Daerah, maka harapan dari berbagai program dari pemerintah pusat bertujuan untuk mengurangi jumlah rumah tidak layak huni guna mendukung program sejuta rumah di Indonesia khususnya bagi Masyarakat Berpenghasilan Rendah (MBR) untuk meningkatkan hunian masyarakat. Pembangunan perumahan baru terus dilakukan karena permintaan akan perumahan tersebut meningkat seiring dengan jumlah penduduk Kabupaten Lahat yang semakin meningkat pula. Akan tetapi pembangunan perumahan saat ini lebih banyak untuk pembangunan menengah sehingga pembangunan rumah sederhana menjadi terabaikan. Yang menjadi salah satu sebab adalah belum optimalnya perizinan pembangunan perumahan bagi masyarakat berpenghasilan rendah.

Dalam penyelenggaraan perizinan perumahan bagi masyarakat berpenghasilan rendah telah terbit Peraturan Menteri Dalam Negeri Nomor 55 Tahun 2017 Tentang Pelaksanaan Perizinan dan Nonperizinan Pembangunan Perumahan Bagi Masyarakat Berpenghasilan Rendah (MBR) sebagai kebijakan nasional yang mengamatkan daerah untuk menerbitkan Peraturan Kepala Daerah tentang Kemudahan Perizinan Pembangunan Perumahan bagi Masyarakat Berpenghasilan Rendah. Maka dalam rangka percepatan Pelaksanaan Perizinan Pembangunan Perumahan Bagi Masyarakat Berpenghasilan Rendah di Kota Palembang maka Gubernur Sumatera Selatan telah mengeluarkan Surat Edaran No 056/Se/Perkim/2019 tentang Kemudahan Perizinan Pembangunan Rumah Bersubsidi bagi Masyarakat di Sumatera Selatan untuk memberi arahan kepada Kabupaten/ Kota dilingkup Provinsi Sumatera Selatan.

Terdapat beberapa faktor penghambat penyelenggaraan perizinan pembangunan perumahan masyarakat berpenghasilan rendah yaitu tumpang-tindih kewenangan antara Undang-Undang Nomor 1 Tahun 2011 tentang Perumahan dan Kawasan Permukiman dan Undang-Undang Nomor 23 Tahun 2014 tentang Pemerintahan Daerah serta pengaturan pelaksana yang mengamahkan pemerintah daerah untuk membentuk regulasi daerah dalam percepatan perizinan dan nonperizinan pembangunan perumahan bagi masyarakat berpenghasilan rendah, namun dalam pengaturan tersebut terbatas hanya pada rumah tapak. Sementara Kota Palembang memiliki keterbatasan lahan untuk pembangunan rumah tapak. Hal inilah yang membuat amanat dari Pasal 10 Peraturan Menteri Dalam Negeri Nomor 55 tahun 2017 tentang Pelaksanaan Perizinan dan Non Perizinan Pembangunan Perumahan Bagi Masyarakat Berpenghasilan Rendah di Daerah tidak dapat berjalan maksimal.

\section{DAFTAR PUSTKA}

Dye, T. R. (1992). Understanding Public Policy. Englewood Cliffs.

Festus, I., \& Amos, I. (2005). Housing Policy in Nigeria: An Overview. American International Journal of Contemporary Research, 5(2), 53-59.

Glaeser, E., \& Gyourko, J. (2018). The economic implications of housing supply. Journal of Economic Perspectives, 32(1), 3-30. 
Hutapea, H., \& Suwandono, D. (2015). Perencanaan Pembangunan Perumahan Baru dan Strategi Pengadaan Tanah Bagi Masyarakat Berpenghasilan Rendah di Kecamatan Banyumanik. Ruang, 2(4), 371-380.

Indradjati, P. N. (2020). Peraturan Zonasi Sebagai Perangkat Kolaboratif Mewujudkan Perumahan untuk Masyarakat Berpendapatan Rendah Di Kawasan Perkotaan. Jurnal Permukiman, 15(2), 61-72.

Iskandar. (2009). Metodologi Penelitian Kualitatif (Pertama). Gaung Persada.

Kawer, O. F. S., Baiquni, M., Keban, Y. T., \& Subarsono, A. (2018). Implementasi Kebijakan pembangunan rumah layak huni dengan pendekatan hibrida di kabupaten supiori provinsi Papua. Sosiohumaniora, 20(3), 245-253.

Mangeswuri, D. R. (2016). Kebijakan Pembiayaan Perumahan Melalui Fasilitas Likuiditas Pembiayaan Perumahan (FLPP). Jurnal Ekonomi \& Kebijakan Publik, 7(1), 83-95.

Mardiansyah, A., \& Adisti, N. A. (2020). Analisis Yuridis Pasal 98 Ayat (3) Undang-Undang Nomor 1 Tahun 2011 Tentang Perumahan Dan Kawasan Permukiman (Kajian Terhadap Penetapan Lokasi Perumahan Kumuh Oleh Pemerintah Daerah Dengan Peraturan Daerah). Jurnal Legislasi Indonesia, 17(4), 451-458.

Nugroho, R. D. (2004). Kebijakan Publik, Formulasi, Implementasi, dan Evaluasi, penerbit PT. Elex Media Komputindo.

Sabaruddin, A. (2012). Arsitektur perumahan di perkotaan. In Panyaungan Cileunyi Wetan Kabupaten Bandung: Puskim.

Sugiyono. (2009). Metode Penelitian Administrasi Dilengkapi Dengan Metode R\&D. Bandung: Alfabeta. Alfabeta.

Waha, C., \& Sondakh, J. (2014). Pemenuhan Hak atas Perumahan yang Layak bagi Masyarakat Miskin di Perkotaan (Suatu Kajian dalam Perspektif Hak Asasi Manusia). Jurnal LPPM Bidang EkoSosBudKum, 1(2), 86-102.

Winarno, B. (2002). Teori dan proses kebijakan publik. Media Pressindo. 